\title{
A COBERTURA JORNALÍSTICA EM MÍDIAS LEGISLATIVAS: UM ESTUDO SOBRE A AGÊNCIA CÂMARA ${ }^{1}$
}

\author{
Leidyanne Viana Nogueira ${ }^{3}$ \\ Francisco Paulo Jamil Marques ${ }^{4}$
}

\begin{abstract}
RESUMO
$\mathrm{O}$ artigo investiga de que maneira o tema "Reforma Política" foi abordado em um conjunto de notícias publicadas pela Agência Câmara a fim de verificar, dentre outros aspectos, em que medida há diversidade de vozes no âmbito de tal veículo de comunicação parlamentar. Após uma breve discussão conceitual (que envolve as particularidades da comunicação em mídias legislativas), o trabalho examina empiricamente, por meio da Análise do Discurso, 17 notícias publicadas pela referida Agência entre julho e outubro de 2013. Em seguida, é oferecida uma discussão sobre a natureza da produção jornalística em tela. Duas hipóteses, fundamentadas na literatura e na proposta editorial da Secretaria de Comunicação da Câmara (Secom), guiam a investigação: H1) De maneira geral, predomina nas notícias o discurso atrelado à construção de uma imagem positiva da Casa; $\mathrm{H} 2$ ) Há uma escassa pluralidade de vozes e perspectivas políticas nas notícias, não obstante os princípios editoriais da Secom defenderem o contrário. De maneira geral, observa-se um tom de discurso oficial em boa parte das notícias que compõem a amostra, com críticas raras ou moderadas aos agentes do campo político, além de se ter verificado uma baixa variedade de fontes no material em questão.
\end{abstract}

Palavras-chave: Câmara dos Deputados; Congresso; Política; Comunicação Institucional; Jornalismo.

\begin{abstract}
The article investigates how the Brazilian House of Representatives' News Agency covers the issue "Political Reform" in order to examine to what extent there is a diversity of voices within that vehicle parliamentary communication. After a brief literature review, the paper empirically examines, by using Discourse Analysis, 17 news published by the News Agency between July and October 2013. Two hypotheses guide our research: H1) Generally speaking, a discourse aimed at building a positiva image of the House and its agents predominates in the regular coverage; H2) There is a narrow plurality of voices and political perspectives in the news, despite the editorial principles of the House of Representatives' News Agency defend the opposite. We found an official speech tone in much of the news in the sample, with rare or moderate criticism towards political agents. Moreover, there has been a low variety of sources in the material at stake.
\end{abstract}

Keywords: House of Representatives; Congress; Politics; Political Communication; Journalism.

\section{RESUMEN}

El artículo investiga cómo se discutió el tema "Reforma Política" en una serie de noticias publicadas por la Agencia de Cámara de los Representantes para verificar, entre otras cosas, en qué medida existe una diversidad de voces dentro de tal vehículo de comunicación parlamentaria. Después de una breve discusión conceptual, el artículo examina empíricamente, por medio del análisis del discurso, 17 noticias publicadas por esa agencia entre julio y octubre de 2013. Dos hipótesis, basadas en la literatura y en los principios editoriales de la Secretaria de Comunicaciones (Secom) orientan la investigación: H1) En términos generales, un discurso dirigido a la construcción de una imagen positiva de la casa y sus agentes predomina en la cobertura noticiosa; H2 ) hay una pluralidad estrecha de voces y perspectivas políticas en las noticias, a pesar de los principios editoriales de la Agencia Cámara defendieren lo contrario. Encontramos un tono de voz oficial en gran parte de las noticias en la muestra, con raras o moderadas críticas a los agentes políticos. Además, se ha considerado una baja variedad de fuentes en el material analisado.

Palabras-clave: Cámara de los Representantes; Congreso; Política; La comunicación política ; Periodismo.

\footnotetext{
${ }^{1}$ Os autores são gratos aos avaliadores anônimos que ofereceram contribuições essenciais à versão final deste trabalho.

${ }^{2}$ Enviado em: 20/09/2016.

Aceito para publicação em: 04/12/2016.

Mestranda do Programa de Pós-Graduação em Comunicação da Universidade Federal do Ceará (UFC). Graduada em Comunicação Social - Jornalismo (UFC). E-mail: leidyanne.viana@gmail.com.

${ }^{4}$ Doutor em Comunicação e Cultura Contemporâneas pela UFBA. Professor do Departamento de Ciência Política (DECP), do Programa de Pós-Graduação em Ciência Política (PPGCP) e do Programa de PósGraduação em Comunicação (PPGCOM) da UFPR. Bolsista de Produtividade em Pesquisa do CNPq. Líder do Grupo de Pesquisa em Comunicação, Política e Tecnologia (PONTE/UFPR).E-mail: marquesjamil@gmail.com
} 
MARQUES, Francisco Paulo Jamil Almeida \& NOGUEIRA, Leidyanne Viana. A cobertura jornalística em mídias legislativas: um estudo sobre a Agência Câmara.

\section{INTRODUÇÃO}

Para Kovach e Rosenstiel (2004), o Jornalismo, não obstante ter passado por várias mudanças nas últimas décadas, permanece fundamental para "fornecer aos cidadãos as informações de que precisam para serem livres e se autogovernarem” (p. 31). Para os autores, contudo, a função social de tal atividade estaria ameaçada, no início do século XXI, por conta do "surgimento de um jornalismo baseado no mercado, mais e mais divorciado da ideia de responsabilidade cívica” (p. 49). Bucci (2008a) aponta um diagnóstico semelhante, destacando que o esforço agora se volta para manter o Jornalismo independente não somente de anunciantes e de governos, mas, também, dos interesses estritamente econômicos dos próprios donos das empresas noticiosas.

$\mathrm{Na}$ tentativa de evitar tais riscos e de fortalecer a ligação da imprensa com o interesse público, um grupo de jornalistas e acadêmicos propôs o conceito de "Jornalismo público". De acordo com Moraes (2011), tal movimento - cujos princípios ou nomenclaturas ainda hoje não são consensuais, sendo denominado, a depender do autor, de "Jornalismo cívico", “comunitário" ou "de serviço público" (TRAQUINA, 2005) - propõe repensar, por exemplo, a ênfase das perguntas clássicas do Jornalismo (quem; o quê; onde; por qual motivo; de que maneira) a fim de destacar a natureza dos problemas coletivos.

Deve-se também perguntar sobre a relação dos cidadãos com essas questões e problemas; com quem se deveria estar falando, sobre o que, onde, quando e como as pessoas podem se envolver na sua deliberação, e por que ele está sendo resolvido ou não (MORAES, 2011).

Destaque-se que mesmo instituições do Estado têm se esforçado para consolidar as experiências de Jornalismo público mundo afora. É o caso da Câmara dos Deputados, que conta com um complexo sistema de comunicação cuja proposta editorial, conforme será detalhado mais à frente, é realizar, dentre outras tarefas, um Jornalismo voltado para o interesse público e para a promoção da cidadania, como suplemento à cobertura política da imprensa tradicional. Contudo, se, nos veículos da Câmara, não haveria, em princípio, um confronto explícito entre a lógica do Jornalismo e a lógica do mercado (em virtude do financiamento provido com recursos públicos), é possível diagnosticar determinados conflitos entre a lógica do Jornalismo e a lógica dos interesses políticos ali presentes, por conta da subordinação hierárquica dos jornalistas aos deputados (BERNARDES, 2010; 2011).

Assim, levando em conta as peculiaridades da Agência Câmara, o trabalho tem como objetivos principais (a) compreender como se dá a abordagem do tema "Reforma Política" em 
um conjunto de notícias elaboradas pela Agência Câmara e (b) verificar em que medida há diversidade de vozes nos materiais examinados. Consideramos que estas duas questões permitem confrontar, de um lado, a proposta de comunicação editorial formulada pela Casa e, de outro, aquilo que é efetivamente praticado no âmbito dos veículos da Câmara. Ademais, pretende-se discutir de que maneira a Agência Câmara produz um conjunto de sentidos sobre a questão da Reforma Política, ao mesmo tempo em que limita a visibilidade de emersão de outros.

Por meio da Análise de Discurso, serão examinadas 17 notícias sobre a Reforma Política, todas publicadas entre julho e outubro de $2013^{5}$. Este tem se mostrado um tema relevante na última década, considerando a quantidade de proposições legislativas aprovadas ou em discussão no Congresso. Além disso, as modificações no comando da Secretaria de Comunicação da Câmara dos Deputados chanceladas pela Mesa Diretora (sobretudo a partir de 2015), que tinha Eduardo Cunha (PMDB-RJ) à frente, atraem a atenção para os efeitos da gestão política na área de comunicação da $\mathrm{Casa}^{6}$. Mesmo que o período mais recente (iniciado a partir de 2015) não seja o foco deste trabalho, é importante observar os efeitos da hierarquização política sobre a produção de conteúdo.

Nesse sentido, ressalte-se que mesmo ao cumprir funções importantes em relação à transparência ou ao potencial de responsividade dos parlamentares, como defende Jardim (2007), dentre os interesses de origem na criação dos veículos da Câmara está a função de promover a imagem dessa instituição. Como se verá adiante, alterações estruturais na proposta da SECOM trataram de separar as funções de comunicação institucional, de um lado, e as jornalísticas, de outro. Até que ponto, contudo, tal divisão é capaz de afastar o interesse institucional na produção de notícias? Para Bucci (2008b), nos canais legislativos, "a finalidade de dar transparência está subordinada a finalidade de promoção" (p. 263). Assim sendo, e com o objetivo de verificar empiricamente tal problema, apresenta-se a primeira hipótese do trabalho:

H1: Mesmo que a proposta editorial da Agência Câmara aponte para a ideia de Jornalismo Público, predomina, nas notícias analisadas, um discurso oficial atrelado à construção de uma imagem positiva da Casa.

\footnotetext{
${ }^{5}$ É importante destacar a pluralidade de propostas (sejam elas teóricas ou legislativas) que envolvem a questão da reforma política no caso brasileiro. Por conta da limitação de espaço, o tema não será aprofundado neste trabalho. Indica-se, de qualquer forma, a leitura de referências a exemplo de Avritzer e Anastasia (2006), Nicolau e Power (2007) e Bresser-Pereira (2015).

6 Ver: < http://goo.gl/OwPzc0 >. Acesso em 03 mai. 2015.
} 
MARQUES, Francisco Paulo Jamil Almeida \& NOGUEIRA, Leidyanne Viana. A cobertura jornalística em mídias legislativas: um estudo sobre a Agência Câmara.

Vale destacar que, embora a possibilidade de vício partidarista da cobertura seja reduzida em virtude da diversidade de legendas na Câmara - como defendem Bernardes (2010), Bucci (2008b) e Sant'Anna (2009) -, tal realidade não é garantia de uma pluralidade de fontes (sobretudo porque uma efetiva variedade de fontes extrapola considerar apenas os parlamentares). Apesar disso, em pesquisa realizada por Queiroz (2007) junto a profissionais da TV Câmara, a pluralidade de fontes foi a opção que mais apareceu como parâmetro exigido pelas chefias na produção diária de matérias. Para a autora:

[...] as matérias produzidas pelos jornalistas das TVs legislativas devem refletir esse aspecto [o perfil pluripartidário] e dar voz a todas as representações políticas. É uma característica importante porque faz com que as matérias reflitam a multiplicidade de vozes da sociedade representadas no parlamento. Tanto parlamentares de partidos majoritários quanto os da minoria devem ser ouvidos (p. 146).

Contudo, a própria autora ressalta que "[e]mbora a preocupação com a pluralidade das fontes esteja presente na produção diária da emissora, muitas vezes essa pluralidade se restringe a ouvir diversos partidos em vez de diversos parlamentares de diferentes partidos" (p. 162). Tal observação encontra respaldo no "oficialismo" constatado por Bernardes:

[...] não são todos os parlamentares que merecem atenção das mídias legislativas. Geralmente, aparecem aqueles que são detentores de cargos e de algum tipo de poder institucional dentro da instância legislativa, com especial privilégio para o presidente da Câmara e para os líderes partidários (2011, p. 178).

Nesse sentido, apresenta-se a segunda hipótese de pesquisa:

H2: Também de forma contrária à proposta editorial que guia o trabalho da Agência Câmara, as notícias relativas à Reforma Política são marcadas por uma escassa pluralidade de fontes.

Com o intuito de verificar as duas hipóteses, o trabalho conta com a seguinte estrutura: os próximos tópicos discutem um conjunto de elementos que envolvem o sistema de comunicação da Câmara, apoiando-se na abordagem dos conceitos de Comunicação Pública, Comunicação Institucional e Jornalismo público. Em seguida, apresentam-se a análise empírica e as principais descobertas da pesquisa. 


\section{COMUNICAÇÃo PÚBLICA E O SURGIMENTO DAS MÍdIAS LEGISLATIVAS NO BRASIL}

Brandão (2012) aponta que o conceito de comunicação pública tem assumido diferentes significados no Brasil, sem haver ainda um consenso. Uma das acepções, segundo a autora, identifica comunicação pública com o fluxo informativo que vai do Estado e do governo para os cidadãos, "uma forma legítima de o governo prestar contas e levar ao conhecimento da opinião pública projetos, ações, atividades e políticas" (BRANDÃO, 2012, p. 5). Sant'Anna (2009), todavia, observa o seguinte:

Comunicação pública não significa dizer que ela se limite à comunicação produzida pelo Estado; ela engloba toda comunicação de interesse público, praticada não só por governos, como também por empresas, terceiro setor e sociedade em geral. (p. 149).

Weber (2007), por sua vez, explica que o termo "comunicação pública" pode ser utilizado tanto por agentes do campo do Jornalismo, quanto por estudiosos e profissionais das Relações Públicas e do Marketing. Para a autora, entretanto, o que definiria comunicação pública seria o ato de promover a "circulação de temas de interesse público, nos modos de debater e repercutir esses temas" (p. 24).

Divergências teórico-conceituais à parte, o fato é que, principalmente a partir da segunda metade do século XX, atores sociais que antes assumiam o papel de fontes jornalísticas passaram a tentar interferir na agenda pública por meio da criação de suas próprias mídias, abrindo espaço para iniciativas que Sant'Anna (2009) denomina de "mídias das fontes".

É nesse contexto que surgem, no Brasil, ao longo dos anos 1990, as chamadas "mídias institucionais" no campo político. O primeiro canal dessa natureza foi a TV Assembleia de Minas Gerais, criada em 1995. A TV Câmara surge em 1998; a Rádio Câmara, por sua vez, em 1999. O último canal a ser lançado pela Câmara foi a Agência Câmara Notícias, no ano 2000 (BARROS; BERNARDES; LEMOS, 2008).

O desenvolvimento das emissoras de comunicação da Câmara deve-se, segundo Barros, Bernardes e Lemos (2008), à avaliação feita por profissionais daquela Casa Legislativa sobre a qualidade da informação fornecida pelas mídias comerciais: em vez de contribuir para um debate público de temas fundamentais, os jornais fomentariam uma percepção negativa das instituições públicas. A produção dessas mídias legislativas, todavia, mantém o emprego de técnicas e rotinas usuais no Jornalismo tradicional. 
MARQUES, Francisco Paulo Jamil Almeida \& NOGUEIRA, Leidyanne Viana. A cobertura jornalística em mídias legislativas: um estudo sobre a Agência Câmara.

Sant'Anna (2009), assim como Bucci (2008b), argumenta que a possibilidade de vício partidarista na cobertura patrocinada pela Câmara seria remota em virtude da diversidade de legendas representadas na Casa. Contudo, considerando a dependência que os canais legislativos têm do mundo da política, Bucci refuta a tese de que tais veículos pratiquem Jornalismo - como defendem autores a exemplo de Bernardes (2010), Queiroz (2007) e Sant'Anna (2009) -, por mais que prestem informações com valor jornalístico.

Vê-se, assim, que a compreensão do papel cumprido por esse tipo de veículo gera controvérsias teóricas significativas. Este trabalho tem o intuito justamente de se debruçar sobre produtos finais da Agência Câmara e, assim, oferecer um elemento empírico adicional ao debate.

\subsection{O sistema de comunicação da Câmara dos Deputados: entre a Comunicação institucional e o Jornalismo público}

O sistema de comunicação da Câmara começou a se organizar em 1971, quando foi fundada a Assessoria de Divulgação e Relações Públicas (ADIRP). A Resolução que criou a ADIRP determinava que caberia a tal órgão "informar e esclarecer a opinião pública a respeito das atividades da Câmara dos Deputados, utilizando, para isso, os veículos de divulgação e as técnicas de Relações Públicas, e assessorar o Presidente em questões de cerimonial"7. No final da década de 1990, a ADIRP deu lugar à Secom (Secretaria de Comunicação).

A estrutura administrativa da Câmara dos Deputados prevê a subordinação da Secom à Mesa Diretora da Casa. A Secom, por sua vez, conta com dois departamentos: o Departamento de Mídias Integradas, ao qual cabe "supervisionar as atividades jornalísticas realizadas pelos veículos de comunicação da Câmara dos Deputados" (é neste órgão onde está abrigada a Agência Câmara); e o Departamento de Relações Públicas e Divulgação, que seria responsável pela promoção institucional da Câmara ${ }^{8}$.

Percebe-se que enfatizar essa separação é elemento fundamental para a imagem de credibilidade que tais veículos se esforçam em construir. Gomes (2004) e Bucci (2008a) se dedicam a apontar a diferença entre as duas atividades: enquanto o Jornalismo deve servir ao

\footnotetext{
${ }^{7}$ Resolução da Câmara dos Deputados no 20, de 1971. Seção IV, "Da Assessoria de Divulgação e Relações Públicas”. Disponível em: < http://goo.gl/bb7dER >. Acesso em: 16 nov. 2015.

${ }^{8}$ Disponível em: < http://goo.gl/mOQixs > Acesso em: 20 ago. 2015.
} 
interesse público e ao direito à informação dos cidadãos, a Comunicação Institucional empenha-se em formar uma opinião pública favorável à instituição a qual está ligada.

É importante frisar que o trabalho da Secretaria de Comunicação passou por reformulações substanciais a partir de um Seminário realizado na Câmara em 2003. Dentre as novidades de tal evento, destaca-se a criação de um Manual de Redação, cuja inspiração central foi:

[...] o princípio de que os veículos da Secom devem preservar e aperfeiçoar sua missão básica: serem instrumento à disposição da sociedade brasileira, para que esta tenha acesso a informações objetivas, isentas e apartidárias sobre os trabalhos legislativos da Câmara dos Deputados (MALAVAZI, 2004, p. 19).

A partir de 2012, uma nova estrutura foi implantada, visando promover uma integração ampla entre os quatro veículos, amparada na ideia de "convergência midiática". Por conta disso, os veículos perderam suas coordenações e ficaram subordinados diretamente à Coordenação de Jornalismo (BERNARDES e MACEDO, 2014). O Manual faz uma distinção na atuação dos veículos da Câmara: enquanto as emissoras de Rádio e TV têm como destinatários diretamente um público mais amplo, o Jornal e a Agência teriam como alvo outros órgãos da imprensa, atuando como fontes para outros veículos. A Agência Câmara Notícias, caso a ser examinado neste artigo, está hospedada no portal da Câmara dos Deputados (http://www2.camara.leg.br/camaranoticias/).

Os veículos de comunicação da Secom são enquadrados na categoria de comunicação pública por estarem vinculados à instituição, mas principalmente por desenvolverem seu trabalho cotidiano segundo o conceito definido pelos dicionaristas. A comunicação da Secom é pública porque assume a responsabilidade de emitir, transmitir e receber mensagens, sempre com o sentido de responsabilidade social. (MALAVAZI, 2004, p. 135).

Segundo o $\mathrm{Manual}^{9}$, a necessidade de comunicação pública é "flagrante”, em virtude das deficiências identificadas pelo documento no que concerne à cobertura da imprensa comercial, que "não tem sido capaz de, sozinha, cumprir o papel de transmissora de toda a vasta gama de informações cuja captação é essencial para o exercício dos direitos de cidadania" (MALAVAZI, 2004, p. 27). Ainda de acordo com o mesmo documento,

Os veículos da Secom devem, assim, disseminar informações sobre as atividades da Câmara dos Deputados, de forma a contribuir para que o conhecimento acurado do processo legislativo gere maior participação da sociedade na própria atividade

\footnotetext{
${ }^{9}$ Para maior aprofundamento sobre a estrutura de funcionamento do Setor de Comunicação da Câmara, ver o Manual de Redação (<http://goo.gl/wdYwuv〉) e o Organograma da Casa (<http://goo.gl//8APdhL 〉). Acesso em 04 mai. 2015.
} 
MARQUES, Francisco Paulo Jamil Almeida \& NOGUEIRA, Leidyanne Viana. A cobertura jornalística em mídias legislativas: um estudo sobre a Agência Câmara.

legislativa - o que, por sua vez, vai torná-la mais democrática (MALAVAZI, 2004, p. 29-30).

Neste sentido, vê-se que a proposta presente no Manual de Redação da Casa aponta para uma prática jornalística pautada pelo interesse público, com vistas a ampliar a participação do cidadão. Conecta-se, assim, à ideia do Jornalismo público na medida em que propõe que os veículos da Câmara produzam informações que permitam à audiência exercer sua cidadania como direito social, por meio da ênfase em temas da seara política. Traquina (2005) explica que o Jornalismo público foi um movimento surgido nos Estados Unidos, no final do século XX, e que dizia buscar reaver a ligação da imprensa com o interesse público e com a cidadania. Segundo Moraes (2011), como premissa defendida pelos primeiros jornalistas públicos e acadêmicos estava o ideal de "facilitar ao máximo a tomada de decisões sobre questões públicas, por parte dos cidadãos, e o encaminhamento dessas questões” (n.p).

A bem da verdade, esta parece uma definição vaga - afinal, pelo menos normativamente, o Jornalismo comercial de boa qualidade adota os mesmos princípios. É nesse ponto que fica mais evidente uma dificuldade conceitual enfrentada pela própria ideia de Jornalismo público.

[...] boa parte da literatura sobre Jornalismo público encobre as inconsistências e mesmo as contradições em suas premissas e princípios. Se todos aqueles que escrevem em favor do Jornalismo público concordam, de forma apaixonada, mas vaga, que a vida pública precisa ser aprimorada e que a imprensa precisa se redefinir e revigorar seu compromisso com a democracia e com a participação democrática, poucos concordam sobre o significado de 'democracia' [...] e sobre qual o papel que a imprensa deve desempenhar para que as coisas funcionem a contento (GLASSER, 1999, p. 7).

Ainda assim, o conceito em questão pode ser útil para elaborar uma análise da cobertura providenciada pela Agência Câmara justamente ao ressaltar quesitos que nem sempre são contemplados pelo Jornalismo comercial, a exemplo de "apelar para um ideal republicano que coloca a política como um espaço de discussão aberto a todos os cidadãos interessados" (GLASSER, 1999, p. 10). Consonante a tal objetivo, o Manual da Secom aponta que "[n]o que diz respeito à linguagem, é essencial que o jornalismo público seja intérprete do processo legislativo e das negociações. Interpretar, nesse caso, não é sinônimo de emitir opiniões: significa traduzir o fato para compreensão comum” (MALAVAZI, 2004, p. 29).

A respeito das ambiguidades que envolvem esses veículos, Bernardes (2010) considera haver um caráter híbrido na produção desses meios: “Ainda que a comunicação institucional exerça forte influência na atividade cotidiana dos profissionais e a intenção 
persuasiva não esteja excluída da produção informativa, acreditamos que parte dessa produção pode ser chamada de Jornalismo público" (p. 233).

Considerando, então, os conflitos e as limitações à atividade jornalística no âmbito do Legislativo, e observando que o Jornalismo comercial também é marcado por disputas de ordens diversas, pretende-se, neste trabalho, estudar dois aspectos refletidos nos argumentos apontados acima, à prática do Jornalismo público: a diversidade de vozes presente na cobertura e o aprofundamento temático sobre um assunto de interesse público. Importante ressaltar que somente estes dois pontos de análise não são suficientes para concluir a respeito do enquadramento da Agência Câmara como representante do Jornalismo público, uma vez que a proposta original deste movimento comporta recomendações relativas ao processo de produção jornalístico, o qual não será tratado neste artigo.

\section{ANÁLISE EMPÍRICA}

\subsection{Estratégias metodológicas}

Opta-se por examinar as notícias em uma sequência cronológica utilizando a vertente francesa da Análise do Discurso, uma vez que, como defende Courtine (2006), este método possibilita desvendar a opacidade dos discursos políticos, o que se aproxima da ideia de Pêcheux (1997a) sobre a necessidade de compreender o discurso de acordo com o "efeito de sentidos" partilhados entre interlocutores - e não como mera transmissão de uma informação ou dado.

Para Charaudeau (2007), analisar o discurso de informação presente nas mídias não é tarefa fácil. Segundo ele, enquanto se admite que o discurso político está intimamente ligado ao poder e à manipulação, o mundo das mídias tem a pretensão de se definir contra o poder e contra a manipulação, entretanto, elas também são utilizadas pelos políticos como um meio de manipulação da opinião pública. Tal consideração se complica em virtude da natureza do veículo que estamos analisando, marcado pelos conflitos entre sua pretensão editorial e sua condição de veículo institucional subordinado a agentes políticos.

Assim, a análise aqui proposta é desenvolvida pela leitura e interpretação dos textos, buscando-se os possíveis efeitos discursivos gerados. Considera-se, então, o tratamento dado à informação nas notícias, pois, segundo Charaudeau (2007):

O tratamento é a maneira de fazer, o modo pelo qual o sujeito informador decide transpor em linguagem [...] os fatos selecionados, em função do alvo predeterminado, com o efeito que escolheu produzir. Nesse processo, está em jogo a inteligibilidade da informação transmitida, e como não há inteligibilidade em si, esta 
MARQUES, Francisco Paulo Jamil Almeida \& NOGUEIRA, Leidyanne Viana. A cobertura jornalística em mídias legislativas: um estudo sobre a Agência Câmara.

depende de escolhas discursivas realizadas pelo sujeito informador. Ora, toda escolha se caracteriza por aquilo que retém ou despreza; a escolha põe em evidência certos fatos deixando outros à sombra (p. 38).

Configura-se, então, um jogo entre o dito e o não-dito, o explícito e o implícito, não perceptível a todos, explica Charaudeau (2007). Seguindo tais noções, o contato prévio com o corpus empírico permitiu observar, dentre outros aspectos, que a construção dos argumentos pelas fontes mencionadas nas notícias parte de perspectivas político-partidárias singulares, isto é, que evidenciam visões de mundo atreladas aos interesses de cada ator. É nesse sentido que o artigo concorda com Benetti (2007a) quando ela explica que "o Jornalismo é, entre outras definições possíveis, um discurso" (n.p.), pois é um "lugar de circulação e produção de sentidos" (BENETTI, 2007b, p. 37).

Ademais, segundo Benetti (2006), a polifonia seria uma condição ideal do texto jornalístico: "Para identificar seu caráter polifônico ou monofônico é preciso mapear as vozes que o conformam, e, nesse movimento, refletir sobre as posições de sujeito ocupadas por indivíduos distintos" (p. 6). Neste sentido, contar com várias fontes em uma mesma unidade textual não representa necessariamente contar com vozes distintas. Assim, seguindo tal orientação, consideramos um texto seja polifônico se ele contemplar uma pluralidade de perspectivas (ou seja, nem é dominado apenas por um discurso, nem se limita ao embate entre dois lados). $\mathrm{Na}$ análise, a polifonia foi considerada apenas em relação às fontes que "falam" diretamente.

Ademais, uma vez que cada suporte midiático implica a lida com dinâmicas e rotinas específicas de produção, aponta-se que existem ditames sociais, históricos, culturais e institucionais que ajudam a entender o próprio discurso construído pela Agência Câmara. Isso significa que os textos que compõem o corpus não podem ser pensados de maneira isolada, sendo essencial sua inserção em um contexto ligado às estruturas, atores e ações por eles empreendidas na dialética discursiva.

Justificada a abordagem, pretende-se verificar as nuances discursivas presentes nos textos, sublinhando-se os aspectos a seguir: 1) quem são os agentes principais desses discursos; 2) de que maneira a Reforma Política é abordada; 3) e com que profundidade os pontos dessa reforma são apresentados ao cidadão. Para este último objetivo, são buscados os seguintes aspectos, considerando algumas das orientações do Jornalismo público (MORAES, 2011): apresentação dos valores centrais do problema, das causas para a sua existência, dos responsáveis, das alternativas para sua solução, bem como dos custos e benefícios envolvidos e das justificativas para a não resolução. 


\subsection{Delimitação do corpus}

O corpus empírico da pesquisa é constituído por 17 notícias relacionadas ao tema "Reforma Política". A opção pelo assunto se deve à grande repercussão e ao amplo debate que ele ganhou após os protestos de junho de 2013. Como consequência das manifestações, o tema voltou à pauta do Congresso, especialmente após Dilma Rousseff (PT) propor a realização de um plebiscito para decidir sobre pontos da Reforma (G1, 2013). O Legislativo Federal, então, passou a discutir a questão com maior ênfase.

As notícias foram selecionadas a partir do primeiro mês após a ocorrência das manifestações, considerando-se apenas os dias úteis: $1^{\mathrm{a}}$ semana do mês de julho, $2^{\mathrm{a}}$ semana de agosto, $3^{\mathrm{a}}$ semana de setembro e $4^{\mathrm{a}}$ semana de outubro. Optou-se por meses subsequentes para que se pudesse verificar a evolução da discussão na Câmara, escolhendo-se semanas alternadas de modo a evitar um direcionamento inapropriado quanto ao método de coleta de dados. Importante salientar que os textos analisados são notícias consolidadas, isto é, produzidas ao final dos eventos cobertos. Supõe-se que estas constituem o produto principal da Agência Câmara, sendo as que possuem o maior potencial informativo.

Os materiais foram encontrados por meio da ferramenta de busca disponível no site da Agência. Buscou-se, então, o termo "reforma política"; as opções de filtros surgem após ser solicitada a pesquisa: inseriram-se, então, os períodos desejados e marcou-se o veículo "Agência Câmara”. Dos resultados, somente é considerado para análise o conteúdo enquadrado no gênero jornalístico "notícia", do tipo consolidada, no formato textual, e que esteja inserido no Tema (editoria) "Política". Foram eliminadas matérias que tratassem do simples agendamento de eventos a serem realizados na Câmara, como reuniões de bancadas. Após estes filtros, chegou-se ao quadro de 10 notícias em julho; 4 notícias em agosto; 2 notícias em setembro; 1 notícia em outubro. Cada unidade textual foi verificada tendo em vista título, lead, fontes e suas respectivas declarações, bem como a presença de links com informações complementares.

A seguir, o artigo oferece uma discussão sobre o teor geral das publicações, sendo destacados (por questões de limitação de espaço) os trechos que mais chamam a atenção quanto à pluralidade de vozes e à profundidade na abordagem do tema. Os links para todas as notícias e reportagens (que contêm os trechos citados entre aspas em cada notícia) encontramse nas notas de rodapé que acompanham os títulos dos textos, permitindo ao leitor conferir in loco detalhes da amostra. 
MARQUES, Francisco Paulo Jamil Almeida \& NOGUEIRA, Leidyanne Viana. A cobertura jornalística em mídias legislativas: um estudo sobre a Agência Câmara.

\section{Análise das notícias de julho de 2013}

Notícia 01: Relator da reforma política sugere perguntas para plebiscito

$\mathrm{Na}$ primeira notícia ${ }^{10}$, destacam-se as perguntas que o deputado Henrique Fontana (PT-RS) sugere para o plebiscito da Reforma Política. Tal parlamentar, por ser relator de uma proposta de reforma que aguarda votação na Câmara, mantém sua condição de fonte autorizada e, por isso, desperta o interesse do profissional que realiza a cobertura.

O texto apresenta os posicionamentos do deputado sobre o tema: além de favorável à realização do plebiscito, Fontana defende a urgência na votação da reforma, dando a entender que os integrantes da instituição não se comportam, usualmente, de forma célere.

Como contraponto à posição do deputado, a notícia utiliza como fonte um cientista político, Carlos Ranulfo: "Apresentar a ideia de uma reforma política como resposta às ruas é um erro, é uma precipitação, e pode jogar uma discussão que é muito complexa, a discussão da reforma política, no calor da rua, o que seria um desastre".

Assim, apesar de se poder questionar a presença somente de um deputado governista na matéria (desprivilegiando a oposição, por exemplo), vê-se que outras fontes, externas à Câmara, cumprem, nessa ocasião, o papel de apresentar uma postura divergente.

Não há, portanto, no caso, um discurso monofônico, uma vez que comparecem pontos de vista distintos - isso, por outro lado, não permite que se fale em polifonia (pluralidade de vozes). Observe-se, ainda, que, com relação à profundidade de tratamento da questão por parte da Agência, não há, nesta matéria, maior destaque dado ao debate dos temas envolvidos na reforma política.

Notícia 02: Congresso recebe hoje proposta de plebiscito sobre reforma política ${ }^{11}$

O título é centrado no papel do Congresso, mesmo sendo este o "receptor" da ação do Planalto (logo, a escolha do título subverte uma lógica do título jornalístico, em que a ênfase, geralmente, recai sobre quem pratica a ação noticiada). Por um lado, evidenciam-se, assim, objetivos institucionais; por outro lado, o lead adota um comportamento distinto ao ser construído da seguinte maneira: “A presidente Dilma Rousseff envia hoje ao Congresso Nacional a mensagem com o pedido de realização de um plebiscito para discutir a reforma

\footnotetext{
${ }^{10}$ Notícia sem assinatura. Disponível em: 〈http://goo.gl/yZYPHg> Acesso em: 10 out. 2015.

${ }^{11}$ Notícia sem assinatura. Disponível em: 〈http://goo.g1/U0cpD2> Acesso em: 10 out. 2015.
} 
política". Fica clara a tensão - presente em outros textos, conforme será averiguado - entre objetivos institucionais e objetivos ligados à deontologia jornalística.

A fonte principal dessa notícia é a presidente Dilma: "Segundo ela, o governo pretende discutir pelo menos dois pontos: financiamento de campanhas e sistema eleitoral". A utilização do verbo "pretende" pode oferecer duas interpretações: a) trata-se apenas de uma diretriz do governo/ b) trata-se de uma diretriz do governo, mas que precisa do apoio do Congresso para seguir adiante, já que Câmara e Senado têm competência para participar dos rumos das decisões. Se considerarmos a segunda alternativa (sem descartar a primeira, naturalmente), pode-se pensar que a ênfase exagerada dada às atribuições do Parlamento em realizar a reforma política acaba gerando um efeito negativo para a imagem dessa instituição: ao repetir diversas vezes que cabe ao Congresso resolver tal questão, é possível julgar que o Legislativo seria o culpado pelo fato de não se ter, até hoje, realizado a reforma. Com relação à pluralidade de vozes nas notícias, verificou-se, na prática, uma monofonia, em virtude da presença predominante da presidente Dilma para tratar da proposta de plebiscito.

Notícia 03: Financiamento de campanhas e voto secreto podem fazer parte do plebiscito ${ }^{12}$

A notícia dá voz aos presidentes, naquela ocasião, da Câmara, Henrique Eduardo Alves (PMDB-RN), e do Senado, Renan Calheiros (PMDB-AL), que apresentam suas respectivas considerações sobre a proposta de plebiscito: "Alves considerou o texto 'respeitoso' com o Congresso, já que deputados e senadores, segundo ele, terão liberdade para definir os temas que farão parte da consulta".

As constantes afirmações de respeito entre os dois poderes refletem, na verdade, uma tensão gerada pela atitude do governo entre agentes do meio político. Isso porque, ao propor um plebiscito como forma de aprovação da Reforma, o Executivo, de certa forma, colocaria em segundo plano a capacidade do Congresso em realizá-la.

A matéria também menciona os pontos inventariados na proposta do governo; porém, limita-se a apontar, de maneira rápida, alternativas possíveis aos encaminhamentos do Executivo. Com relação a isso, vale destacar: há um link, com a chamada "Entenda a proposta do Executivo", que encaminha o usuário para fora do texto. O material extra resume as opções presentes na proposta do plebiscito - sem, contudo, discutir as questões, preferindo ater-se a uma breve descrição. Assim, o objetivo de contribuir para a formação de um cidadão crítico

${ }^{12}$ Notícia assinada por repórteres. Disponível em: 〈http://goo.gl/zeo8Re>Acesso em: 10 out. 2015. 
MARQUES, Francisco Paulo Jamil Almeida \& NOGUEIRA, Leidyanne Viana. A cobertura jornalística em mídias legislativas: um estudo sobre a Agência Câmara.

não se evidencia na notícia. Também não há polifonia no texto, pois somente as vozes dos presidentes das duas Casas legislativas foram consideradas.

Notícia 04: TSE informa prazo mínimo de 70 dias para organizar plebiscito ${ }^{13}$

A redação do primeiro parágrafo desta notícia é confusa com relação à possível data para realização do plebiscito:

O Tribunal Superior Eleitoral (TSE) informou [...] que o prazo mínimo para organizar um plebiscito sobre a reforma política é 70 dias, a contar de $1^{\circ}$ de julho, quando recebeu a consulta da presidente Dilma Rousseff... [...] Com isso, de acordo com o tribunal, o plebiscito poderia ser realizado em 8 de setembro, se as providências para a sua realização fossem tomadas de imediato.

Vê-se que a edição optou, nesta matéria, por enfatizar a probabilidade de realização do plebiscito no prazo esperado pelo governo - algo que depende da agilidade do Congresso em tomar as medidas necessárias. Pode-se dizer que, de certo modo, o TSE passa o encargo para o Congresso, ao mesmo tempo em que se exime da responsabilidade, pois apenas estaria cumprindo o prazo necessário para os procedimentos. Aqui, uma vez mais, o Legislativo é responsabilizado, ainda que de maneira muito breve. Não se nota a presença de uma voz institucional, que poderia rebater a perspectiva do TSE. Contudo, também não há polifonia nem a discussão de assuntos atinentes à reforma política.

Notícia 05: Plebiscito pode sanar déficit de representatividade, acredita líder do governo $^{14}$

O lead da notícia aponta objetivamente a posição de um parlamentar em específico: "O líder do governo na Câmara, deputado Arlindo Chinaglia (PT-SP), defendeu nesta terçafeira a proposta do Poder Executivo de realizar a reforma política a partir de um plebiscito.” No período seguinte, consta o trecho: "Segundo Chinaglia, a decisão da base governista, tanto na Câmara como no Senado, foi tomada após reunião com a presidente Dilma Rousseff na semana passada".

Ou seja, vai-se de uma decisão isolada do deputado (defesa do plebiscito) para a informação de que a decisão "da base" foi tomada após reunião com a presidente. Tem-se, então, uma informação implícita: a base aliada apoia o plebiscito. Chinaglia, contudo, nega enfaticamente, na matéria, que tenha havido uma imposição do Planalto quanto a ser favorável à consulta à população.

\footnotetext{
${ }^{13}$ Notícia sem assinatura. Disponível em: <http://goo.gl/YNHpCL> Acesso em: 10 out. 2015.

${ }^{14}$ Notícia com assinatura de repórteres. Disponível em: <http://goo.gl/QPD46W> Acesso em: 10 out. 2015.
} 
Em seguida, a notícia aponta a existência de uma posição divergente na Câmara: "Em declarações à imprensa, por outro lado, líderes de oposição apoiam a realização de um referendo." Contudo, não se utiliza como fonte membro algum da oposição para defender o referido ponto de vista, generalizando a posição de quem é contra a iniciativa.

Assim, a matéria fica restrita à apresentação de argumentos favoráveis ao plebiscito. Revela-se um discurso monofônico, uma vez que ele permanece centrado nas opiniões e nas declarações de um único deputado, que é líder do governo.

Notícia 06: Sugestão de Dilma para plebiscito repercute entre políticos e especialistas ${ }^{15}$

A notícia dá destaque ao vice-presidente, Michel Temer (PMDB), que, na época, atuava na defesa do plebiscito. O jornalista autor da matéria utiliza-se, neste caso, do discurso indireto: “[...] o vice-presidente da República, Michel Temer, fez questão de ressaltar que, dos pontos de vista político e acadêmico, o plebiscito é o instrumento mais democrático de consulta popular". Vê-se que, ao escolher o verbo "ressaltar" para introduzir a fala de Temer, o redator induz a interpretação para uma aceitação do discurso que vem em seguida.

Junto à defesa do plebiscito, a matéria reafirma o respeito de Temer pela competência do Congresso: "Constitucionalmente e legalmente, tudo começa e termina aqui, no Congresso. Então, quando se vai marcar o plebiscito e qual será a sua forma são decisões do Congresso Nacional".

Nesta mesma notícia, o ministro da Justiça, José Eduardo Cardozo, rebate o argumento (cuja autoria não é possível identificar a partir da edição) de que os cidadãos seriam incapazes de apreciar da maneira devida os aspectos da reforma política, por se tratar de um tema complexo. Outros dois representantes do governo ganham espaço: Arlindo Chinaglia (PT-SP) e o líder do PT, José Guimarães (CE).

A perspectiva dos oposicionistas ao projeto também é contemplada no texto, da seguinte maneira: "Entre os adjetivos usados pela oposição para classificar as sugestões de Dilma estão 'factoide', 'cortina de fumaça' e 'proposta diversionista'”.

O texto informa que Ronaldo Caiado (DEM-GO) "também não poupou críticas aos cinco pontos sugeridos por Dilma para o plebiscito". Contudo, não são evidenciadas pela matéria as críticas que o deputado elaborou.

O privilégio concedido ao jogo acusatório e de mera troca de farpas entre governo e oposição é um dos males que o Jornalismo público se propõe a combater. É verdade que a

${ }^{15}$ Notícia com assinatura de repórteres. Disponível em: <http://goo.gl/4DGTUI> Acesso em: 10 out. 2015. 
MARQUES, Francisco Paulo Jamil Almeida \& NOGUEIRA, Leidyanne Viana. A cobertura jornalística em mídias legislativas: um estudo sobre a Agência Câmara.

matéria procurou contemplar vozes que representam pontos de vista contrários, governistas e oposicionistas, a fim de alimentar ataques, mas o espaço concedido ao bloco de apoio à perspectiva do Executivo foi mais privilegiado, deixando-se de aprofundar as ressalvas à proposta encaminhadas pelos que estão fora da base do governo.

Notícia 07: Plebiscito sobre reforma política divide opiniões entre líderes partidários ${ }^{16}$

A notícia 07 traz como informação principal a falta de consenso sobre a realização do plebiscito, constatada após reunião entre as lideranças da Câmara. Há dois pontos de discordância: o modo escolhido para fazer a reforma e o prazo defendido pelo governo.

José Guimarães (PT) repassa as alternativas surgidas da reunião: a defesa do plebiscito ainda em 2013, proposta da presidente Dilma; a realização do plebiscito em 2014, juntamente com as eleições; e a votação de uma reforma política pelo Congresso, condicionada a um referendo. Verifica-se, assim, que a informação de que a base aliada estaria majoritariamente comprometida com o plebiscito, repassada por Arlindo Chinaglia (PT-SP), como visto na notícia 05 , fica comprometida.

Na sequência, apresentam-se críticas à proposta governista. Ronaldo Caiado (DEM) afirma que "desenhar para a sociedade que o plebiscito vai surtir efeito para 2014 não é verdade, é uma armadilha".

No parágrafo seguinte, mostra-se que a base aliada do Planalto não está, de fato, apoiando a proposta de plebiscito nos termos que o governo defende. O deputado Eduardo Cunha (PMDB-RJ), que, à época, atuava à frente do PMDB governista, afirma: "A bancada apoia a consulta popular, seja ela plebiscito ou referendo, desde que seja feita em 2014".

O conteúdo alocado no intertítulo "Plebiscito x referendo" não abre espaço para a abordagem do tema de forma aprofundada. $\mathrm{O}$ foco é dado, novamente, ao jogo declaratório e acusatório, sem se buscar compreender a consequência da reforma.

Pode-se dizer que houve mais diversidade em relação aos discursos políticos, uma vez que os deputados de oposição contaram com mais espaço para apresentar seus pontos de vista. A matéria ainda careceu, contudo, da participação de setores alheios ao Executivo ou ao Legislativo.

Notícia 08: Presidente vai criar grupo de trabalho para fazer proposta de reforma política ${ }^{17}$

\footnotetext{
${ }^{16}$ Notícia com assinatura de repórteres. Disponível em: <http://goo.gl/ojYLmm> Acesso em: 10 out. 2015.

${ }^{17}$ Notícia com assinatura de repórteres. Disponível em: <http://goo.gl/KB0Y1J>Acesso em: 10 out. 2015.
} 
Nesta notícia, a única fonte é o presidente da Câmara, o então deputado Henrique Eduardo Alves, que anuncia a criação de um grupo de trabalho para elaborar um projeto de reforma. Esta informação é passada de maneira curta e objetiva, apenas como se fizesse parte de mais um procedimento burocrático. Não se problematiza o fato de haver outras propostas já em andamento, como aquela relatada por Henrique Fontana (PT), nem de esta medida poder significar uma rejeição implícita à proposta de plebiscito.

Para afastar a impressão de que não apoia o plebiscito, Henrique Alves informa que se trata de uma "alternativa". Vê-se que ele coloca sobre o Congresso a responsabilidade em realizar a reforma, pois este "já devia tê-lo feito" em resposta às manifestações populares, alinhando-se, assim, à perspectiva do governo. O texto da notícia, então, é monofônico e seu tom adota um caráter institucional.

\section{Notícia 09: Comissão sobre plebiscito será instalada na terça, anuncia Fontana ${ }^{18}$}

Nesta notícia, também é feito o anúncio de um procedimento específico do processo legislativo: a instalação de uma comissão para discutir a proposta do plebiscito. A informação é dada por Henrique Fontana, que tem destaque por ser relator da proposta de Reforma Política. A matéria segue, assim, uma lógica própria à atividade jornalística: aqueles que estão à frente de decisões e projetos importantes são os que ganham visibilidade.

É preciso assinalar que essa notícia é uma das poucas a expandir a discussão sobre a Reforma Política, ao utilizar um infográfico (produzido alguns anos antes, é verdade, em 24/03/2011) ${ }^{19}$. Tal recurso, no caso, (1) informa que o "Congresso Nacional discute propostas de reforma política há décadas"; (2) indica que alterações no sistema eleitoral significariam mudanças na Constituição e (3) apresenta um conjunto de alternativas referentes a essas mudanças, listando vantagens e desvantagens dessas opções. Mais claramente, são expostos os prós e contras relativos aos seguintes temas: financiamento de campanhas, cláusula de barreira, voto facultativo, candidatura avulsa, data de posse, fidelidade partidária, suplência de senadores e reeleição.

No trecho que abre o intertítulo "Processo longo", afirma-se o seguinte: "O processo para o plebiscito se refletir nas eleições é longo. Por isso, a decisão das ruas só deverá valer para as eleições de 2016". O curioso, porém, é que, neste caso, não se atribui a informação a fonte alguma. Por fim, o deputado Fontana opina diretamente sobre a proposta da presidente

\footnotetext{
${ }^{18}$ Notícia sem assinatura. Disponível em: <http://goo.gl/p9gwN0> Acesso em: 10 out. 2015.

${ }^{19}$ Disponível em: <http://goo.gl/1d7dMI> Acesso em: 30 ago. 2015.
} 
MARQUES, Francisco Paulo Jamil Almeida \& NOGUEIRA, Leidyanne Viana. A cobertura jornalística em mídias legislativas: um estudo sobre a Agência Câmara.

Dilma de fazer um plebiscito, considerando-o "bastante razoável, pois o assunto vem sendo discutido pelo Parlamento há 18 anos, sem consenso".

Tem-se, nesta notícia, um texto marcado pela monofonia, uma vez que só temos o posicionamento de um deputado. Mesmo que o texto se esquive de aprofundar o embate plebiscito x referendo, ele acaba apresentando, por meio do infográfico, questões importantes relativas à discussão da Reforma.

Notícia 10: Plebiscito sobre reforma política só valerá para 2016, aponta base do governo ${ }^{20}$

A informação principal se refere à constatação de que não há tempo para o plebiscito da Reforma valer para as eleições de 2014. A notícia resulta de uma reunião do vicepresidente, Michel Temer, e de ministros com a base do governo na Câmara.

O que se destaca textualmente é a necessidade de mais tempo para reflexão. A declaração do deputado Jovair Arantes (PTB), publicada na matéria, vem nesse sentido: "É evidente que não poderíamos atropelar a legislação atual e a Constituição, sob pena de não termos um resultado que a sociedade possa absorver como positivo".

Uma imagem positiva da Câmara é discretamente apresentada no texto, ao se falar da disposição dos deputados em votar "uma série de mudanças eleitorais", que já vinham sendo discutidas por um grupo de trabalho da Casa. Trata-se de uma "minirreforma", como diz um intertítulo.

A proposta de plebiscito do governo volta a ser abordada na notícia a partir de críticas da oposição. Ronaldo Caiado (DEM-GO) e Carlos Sampaio (PSDB-SP), deputados na época, acusam a presidente de estar ouvindo o seu marqueteiro, e não os anseios da população. No desfecho, porém, a fala do ministro da Justiça, José Eduardo Cardozo, ameniza as ressalvas ao plebiscito e acusa a oposição de falta de argúcia em perceber os desejos da população.

A matéria em tela apresentou diversas fontes com posicionamentos divergentes entre si, especialmente no conflito governo x oposição, mas é importante salientar um embate que aparece apenas de modo implícito na sequência do texto, a saber, aquele que destaca as divergências internas no governo sobre qual procedimento adotar a fim de dar sequência à Reforma. Ademais, não se propicia o debate sobre os temas envolvidos na reforma política, nem se explicam os possíveis caminhos para fazê-la.

\section{Análise das notícias de agosto de 2013}

${ }^{20}$ Notícia com assinatura de repórteres. Disponível em: 〈http://goo.gl/1Dm7vj> Acesso em: 10 out. 2015. 
Notícia 11: Reforma política pode aumentar participação das mulheres, avalia deputada ${ }^{21}$

Já no segundo mês após a ocorrência das manifestações de Junho de 2013, vê-se que a quantidade de matérias produzidas a respeito da reforma política foi significativamente reduzida.

A Notícia 11 trata de uma sessão solene no Congresso realizada em homenagem aos 25 anos de fundação da ONG União Brasileira das Mulheres (UBM). Na ocasião, o assunto "reforma política" é mencionado quando se apresenta o problema da baixa participação das mulheres na política brasileira.

A deputada Jô Moraes (PCdoB-MG) é apresentada como fonte relevante por ter sido a primeira presidente da UBM. Curioso notar que, na maioria das matérias que se analisou até aqui, as fontes da Câmara eram parlamentares que ocupavam papeis de liderança na Casa. Neste caso, a ligação da deputada (que não exercia liderança parlamentar) à entidade homenageada significa que a cobertura não escapa aos critérios jornalísticos que conferem autoridade a fontes associadas ao evento em questão.

No último tópico da matéria, o presidente do Senado, Renan Calheiros, faz uma avaliação positiva dos avanços em relação aos direitos das mulheres, apontando "votações recentes do Congresso que [as] beneficiaram". Uma lista de tais leis que teriam beneficiado as mulheres é apresentada, mas sem que a informação seja atribuída ao senador. O jornalista, neste caso, torna-se responsável pela informação adicional, reforçando o que disse o presidente do Congresso. Têm-se, então, indícios de interesses institucionais no processo de apuração da notícia.

Notícia 12: Presidente da CCJ manifesta apoio à proposta popular de reforma política ${ }^{22}$

A Notícia 12 trata de uma proposta de reforma política apresentada por várias entidades da sociedade civil, dentre as quais a Ordem dos Advogados do Brasil (OAB) e o Movimento de Combate à Corrupção Eleitoral (MCCE). A matéria, contudo, dá destaque, no título e no lead, ao apoio do presidente da Comissão de Constituição e Justiça (CCJ), Décio Lima (PT-SC), a essa proposta, assumindo, assim, um ponto de vista institucionalizado. "Assino o projeto para contribuir com sua celeridade, fazer com que ele comece a tramitar formalmente na Câmara", é a declaração de Décio presente na matéria.

\footnotetext{
${ }^{21}$ Notícia sem assinatura. Disponível em: <http://goo.gl/f4sNpA> Acesso em: 10 out. 2015.

22 Notícia com assinatura de repórteres. Disponível em: <http://goo.gl/9FnOjv>Acesso em: 10 out. 2015.
} 
MARQUES, Francisco Paulo Jamil Almeida \& NOGUEIRA, Leidyanne Viana. A cobertura jornalística em mídias legislativas: um estudo sobre a Agência Câmara.

Os representantes das entidades, por sua vez, cobram agilidade no trâmite da proposta. A matéria pressiona os parlamentares, ainda que indiretamente, a adotarem medidas no sentido de promover mudanças no marco político-eleitoral do país.

Apesar de a matéria ter se iniciado com um caráter institucional, ela amplia sua abordagem e dá destaque ao discurso de quem não faz parte dessa instituição, uma entidade externa. O discurso do presidente da OAB, Marcus Vinícius, apresenta uma crítica direta ao Parlamento: “A Lei da Ficha Limpa foi aprovada pelo Senado em 48 horas, e o Congresso já discute a reforma política há 20 anos. O acúmulo de informações é muito grande, não há justificativa que impeça a votação".

A crítica ao Congresso é endossada pelo deputado Henrique Fontana (PT-RS), que assume um discurso de apoio às entidades bem mais forte do que aquele do presidente da CCJ. A última fonte da matéria é um deputado de oposição, Ronaldo Caiado (DEM-GO), que também se diz favorável à proposta intitulada como "popular".

Esta matéria realiza um debate mais rico acerca de alguns aspectos da reforma; apresenta, ademais, uma maior diversidade de pontos de vista, pela presença tanto de deputados governistas como da oposição e de entidades da sociedade civil.

Notícia 13: $P T, P S B, P D T$ e PCdoB colhem assinaturas para plebiscito sobre reforma política $^{23}$

A Notícia 13 trata da união de alguns partidos da base do governo em torno da proposta de plebiscito. O anúncio é feito por André Figueiredo (PDT-CE) e José Guimarães (PT-CE), que demonstra otimismo: "Conseguimos chegar a um consenso sobre esses três pontos e agora vamos à luta para conseguir as assinaturas". A expressão "vamos à luta" acrescenta um sentido de que os deputados governistas estão "batalhando" para conseguir fazer a reforma. O deputado André Figueiredo, por sua vez, menciona a dificuldade para o plebiscito se concretizar para 2014, como queria o governo: “[...] [André] reconheceu que as mudanças, se aprovadas, dificilmente valerão para as eleições de 2014...".

Vê-se, com o uso do verbo "reconheceu" e do advérbio "dificilmente", que a questão do tempo é tratada com cautela pelos deputados governistas, que parecem estar admitindo algo a contragosto. No entanto, o deputado do PDT aponta um aspecto positivo, apesar do adiamento, que é o fato de o momento político ser propício a mudanças. Na matéria em

${ }^{23}$ Notícia com assinatura de repórteres. Disponível em: 〈http://goo.gl/Ykp4Bx>. Acesso em: 10 out. 2015. 
questão, a discussão não é expandida, limitando-se a noticiar a iniciativa de um grupo de parlamentares.

Notícia 14: Financiamento de campanha causa polêmica em audiência sobre reforma política $^{24}$

Aborda-se audiência pública realizada pelo grupo de trabalho (GT) que analisa a reforma política. As entidades participantes são a Ordem dos Advogados do Brasil (OAB), a União Nacional dos Estudantes (UNE) e a Transparência Brasil. O foco da matéria é a polêmica gerada em torno do financiamento de campanhas.

O deputado Cândido Vaccarezza (PT-SP), presidente do GT, apresenta um posicionamento contrário ao de Marcos Vinícius, presidente da $\mathrm{OAB}$, que havia defendido a inconstitucionalidade das doações por parte de empresas:

Não é sério dizer que, se alguém contribuiu para a campanha, manda no deputado. Em mim e na maioria dos deputados aqui na Casa ninguém manda. Eu não vejo os deputados votarem de acordo com quem contribuiu com sua campanha, como eu não vejo os governadores fazerem isso nem a presidente da República.

Vê-se que o deputado assume uma postura de defesa, ao dizer que "em mim [...] ninguém manda". Ao afirmar também que "na maioria dos deputados [...] ninguém manda", Vaccarezza deixa uma parte dos deputados de fora desse argumento. No entanto, ele se corrige no trecho seguinte, dizendo que não vê nenhum político agir sob tal condição.

A UNE, por sua vez, prega o financiamento exclusivamente público de campanhas. $\mathrm{O}$ argumento do representante da entidade, Thiago Aguiar, é o de que "no sistema atual, quem elege não é quem tem o melhor programa, mas que tem mais dinheiro". Por último, tem-se o posicionamento da ONG Transparência Brasil, por meio de seu diretor-executivo Cláudio Abramo, para quem o financiamento deve continuar sendo misto.

Nesta matéria, foi privilegiada uma discussão mais aprofundada sobre os aspectos envolvidos em um dos pontos da reforma política, e isto foi feito amparando-se nos argumentos apontados por entidades da sociedade civil. A matéria, assim, confere maior profundidade ao debate sobre o tema, aproximando-se de uma pluralidade de perspectivas enunciadas que caracteriza a polifonia reivindicada pela proposta da Agência Câmara. Ademais, fica mais claro, nesse caso, em que medida a rotina legislativa ajuda a direcionar os modos de abordagem dos acontecimentos considerados relevantes pela Agência.

${ }^{24}$ Notícia com assinatura de repórteres. Disponível em: 〈http://goo.gl/DBJ3KI>. Acesso em: 10 out. 2015. 
MARQUES, Francisco Paulo Jamil Almeida \& NOGUEIRA, Leidyanne Viana. A cobertura jornalística em mídias legislativas: um estudo sobre a Agência Câmara.

\section{Análise das notícias de setembro de 2013}

Notícia 15: Deputados vão analisar a minirreforma eleitoral aprovada no Senado ${ }^{25}$

A Notícia 15 trata da minirreforma aprovada pelo Senado e que precisa ser votada na Câmara. Vale ressaltar que, no início da notícia, indica-se o que a Câmara está fazendo em relação à reforma política (destacando-se, especificamente, o papel da Casa). A segunda parte da matéria, intitulada "Reforma na Câmara", apresenta os debates que estão em andamento: "Na Câmara, a reforma política já está sendo discutida em várias instâncias", o que, novamente, implica um tom de promoção oficial dos trabalhos da Casa.

Em outras palavras, a notícia se esforça para expor o empenho da Câmara na realização da reforma, adotando um discurso claramente oficial, possibilitando dizer, inclusive, que o texto aproxima-se de um release.

Notícia 16: Urgência do Código de Mineração pode atrasar votação da minirreforma até dia $5^{26}$

A notícia trata da possibilidade de atraso na votação da minirreforma encaminhada pelo Senado. O motivo seria a urgência na tramitação do Código de Mineração. Apesar de o título destacar o provável atraso, o lead apresenta uma perspectiva positiva: "O presidente da Câmara [...] considera possível a votação do projeto de lei da minirreforma eleitoral do Senado a tempo de valer para as eleições do ano que vem". Contudo, segue o argumento, os deputados teriam se deparado com um entrave (a urgência do código de Mineração) cuja responsabilidade é do governo. Vê-se que a matéria serve para atribuir ao Executivo a culpa por uma possível demora na aprovação da minirreforma, o que exime a Câmara de ainda não ter votado o texto. O presidente da Casa, Henrique Alves, é a única fonte a falar sobre essa votação.

Na segunda parte da Notícia 16, são apresentadas algumas das mudanças propostas na minirreforma, de modo mais crítico em relação ao que foi feito na Notícia 15. "Entre outros pontos, a proposta abre brecha para que concessionárias de serviços públicos repassem dinheiro a candidatos e partidos indiretamente por meio de outras empresas. Atualmente, elas são proibidas de doar para campanhas." Destaca-se o uso da expressão "abre brecha”, que sugere a ideia de algo negativo, como, por exemplo, uma doação não contabilizada

\footnotetext{
${ }^{25}$ Notícia sem assinatura. Disponível em: 〈http://goo.gl/zCwTbp〉. Acesso em: 30 ago. 2015.

${ }^{26}$ Notícia com assinatura de repórteres. Disponível em: 〈http://goo.gl/JVX4PF>. Acesso em: 10 out. 2015.
} 
diretamente. Tem-se, assim, um indício de que a notícia procura "driblar" o caráter institucional da sua primeira parte, cumprindo a função jornalística de evidenciar os aspectos envolvidos nas tomadas de decisões políticas.

\section{Análise da notícia de outubro de 2013}

Notícia 17: GT da Reforma Política vai propor voto facultativo e teto de gastos na campanha $^{27}$

A última notícia da amostra informa acerca de algumas deliberações do GT que discute a reforma política sobre voto facultativo e teto de gastos na campanha. De início, explica-se que o teto deverá ser definido a cada eleição pelo Congresso, ficando a cargo do partido decidir se vai cumpri-lo com financiamento privado, público ou misto. Vê-se que os argumentos apontados por setores da sociedade civil na audiência do GT (Notícia 14) não possuíram efeito algum sobre os deputados. Contudo, esse fato não é problematizado na matéria. Passa-se apenas à descrição literal do que determina a proposta.

A última parte da notícia trata da iniciativa popular de reforma política, defendida pela deputada Luiza Erundina. A falta de contextualização e a desordem no relato dos acontecimentos dificultam a compreensão do que ocorreu na Câmara naquele momento. Não se diz, por exemplo, que a referida proposta popular é uma alternativa à proposta do GT, e não algo complementar, como pode parecer. Falta, além disso, "traduzir" as opções em jogo no universo legislativo e mostrar quais delas têm maior viabilidade para se concretizar. A declaração de Erundina ao final da matéria é o único contraponto feito por um ator político.

\footnotetext{
"Uma das queixas da sociedade é exatamente o descompasso entre o que é discutido na Câmara e na sociedade civil", salientou Erundina. A proposta [popular] prevê o financiamento público exclusivo de campanha e proíbe doações de empresas.
}

Vê-se, na matéria sob análise, um formato quase que de relato sobre o trabalho dos parlamentares: apenas são descritas as mudanças propostas, sem questionamento ou problematização. Não há polifonia: a presença de uma voz discordante no final da matéria não chega a mudar o teor da notícia. Em suma, o caráter institucional, na forma de um relato descritivo, predomina.

${ }^{27}$ Notícia com assinatura de repórteres. Disponível em: <http://goo.gl/SHGPG8>. Acesso em: 10 out. 2015. 
MARQUES, Francisco Paulo Jamil Almeida \& NOGUEIRA, Leidyanne Viana. A cobertura jornalística em mídias legislativas: um estudo sobre a Agência Câmara.

\section{DISCUSSÃO DOS RESULTADOS E CONCLUSÕES FUNDAMENTAIS}

A análise aponta que a produção jornalística da Agência Câmara Notícias é feita, em boa medida, em função das atividades legislativas e das movimentações parlamentares, o que condiz com o objetivo de sua criação: dar mais visibilidade ao que acontece na Câmara (MALAVAZI, 2004). Assim, a quantidade de matérias sobre determinado tema acaba sendo reflexo da atenção que ele recebe nessa Casa: as dez notícias sobre Reforma Política na primeira semana de julho de 2013 mostram que esse assunto estava em destaque na pauta, consequência das manifestações do mês anterior. Contudo, quando se chega à quarta semana de outubro desse mesmo ano, só há uma notícia, evidenciando uma abordagem mais escassa.

Verifica-se que uma parte relevante das notícias adota um tom institucional quando se limita a cobrir eventos organizados na Casa, ou ao privilegiar a voz dos líderes (sejam eles do governo ou da oposição), ou quando busca apresentar, ainda que sutilmente, uma imagem positiva da Câmara. Aqui, fica mais clara a tensão entre (1) a obediência às regras estabelecidas pela rotina jornalística (afinal, entrevistar autoridades relacionadas à discussão sobre reforma política é norma profissional, considerando-se o princípio do valor-notícia) e (2) a pressão política para que a Agência Câmara promova a imagem pública de determinados agentes e suas respectivas posições. Assim sendo, resta confirmada a Hipótese 1, que se refere à ideia de que, nas notícias que compõem a amostra, predomina um discurso oficial atrelado à construção de uma imagem positiva da Casa se confirma.

Tal disposição leva a refletir sobre em que medida aspectos relacionados ao Jornalismo podem sobressair no caso da Agência, uma vez que esta é a proposta editorial da Secom. Mesmo que a proposta seja cobrir, dentre outros temas, eventos realizados na Câmara, a questão a ser verificada é se o conteúdo reivindicado como jornalístico não se limita apenas a reproduzir a voz de autoridades legislativas. Quando isso ocorre, o que a Câmara denomina de notícia acaba se confundindo com material promocional.

Especificamente com relação à presença de vozes nas notícias estudadas neste artigo, verifica-se um elevado número de matérias com fontes da base governista (14 notícias ou mais de $80 \%$ do total), ante a presença da oposição (apenas quatro notícias, ou pouco mais de 20\%). Ou seja, além de a cobertura privilegiar o cotidiano institucional, a perspectiva daqueles que são maioria numérica na Casa predomina - o que não permite marcar uma diferença nítida em relação ao que faz o Jornalismo comercial, contrariando o discurso defendido pela própria proposta da Secretaria de Comunicação. Vale destacar, ademais, que a oposição só aparece como contraponto aos que defendem o governo (a base de apoio ao 
governo é fonte em todas as notícias em que os oposicionistas estão). A tabela abaixo indica as fontes presentes em cada notícia.

Tabela 2: Presença de fontes nas notícias analisadas. Elaborada pelos autores.

\begin{tabular}{|l|c|r|}
\hline \multicolumn{1}{|c|}{ Características } & Números das notícias & Quantidade \\
\hline Notícias com fontes do Executivo & $02,06,10$ & 3 \\
\hline $\begin{array}{l}\text { Notícias com parlamentar(es) } \\
\text { governista(s) }\end{array}$ & $01,03,05,06,07,08,09,10,12$, & 4 \\
\hline Notícias com deputado(s) da oposição & $13,14,16,17$ & 3 \\
\hline Notícias com fonte do Judiciário & $06,07,10,12$ & 2 \\
\hline Notícias com especialista(s) & $01,02,04$ & 1 \\
\hline Notícias com representantes de & 01,06 & 1 \\
entidades externas & 12,14 & 11 \\
\hline $\begin{array}{l}\text { Notícia com base em discursos no } \\
\text { Plenário }\end{array}$ & & 15 \\
\hline Notícia sem fontes & & 2 \\
\hline
\end{tabular}

Ainda com relação às fontes, é importante destacar a baixa quantidade de notícias que contaram com a participação de especialistas ou representantes de entidades da sociedade civil. Foram apenas quatro textos, sendo que, no caso das entidades, essas fontes foram ouvidas porque participaram de eventos realizados na própria Câmara. Acerca da polifonia nas notícias examinadas, obteve-se, então, o seguinte panorama:

Tabela 3: Diversidade de vozes nas notícias analisadas. Elaborada pelos autores.

\begin{tabular}{|l|c|r|}
\hline \multicolumn{1}{|c|}{ Características } & $\begin{array}{l}\text { Números das } \\
\text { notícias }\end{array}$ & Quantidade \\
\hline Notícias monofônicas & $\begin{array}{c}02,03,04,05,08, \\
09,13,15\end{array}$ \\
\hline $\begin{array}{l}\text { Notícias nem monofônicas nem polifônicas (isto porque } \\
\text { são apresentados apenas dois lados, o que não pode ser } \\
\text { entendido como pluralidade) }\end{array}$ & $01,07,10,11,16$, & 6 \\
\hline
\end{tabular}


MARQUES, Francisco Paulo Jamil Almeida \& NOGUEIRA, Leidyanne Viana. A cobertura jornalística em mídias legislativas: um estudo sobre a Agência Câmara.

\begin{tabular}{|l|c|r|}
\hline $\begin{array}{l}\text { Notícia polifônica, mas com privilégio a um dos pontos } \\
\text { de vista (do governo) }\end{array}$ & 06 & 1 \\
\hline Notícias polifônicas & 12,14 & 2 \\
\hline
\end{tabular}

Percebe-se um predomínio de discursos de parlamentares (com vantagem para as posições governistas), o que impede a concretização da pluralidade proposta pela Secretaria de Comunicação. Dessa maneira, também foi possível comprovar a Hipótese 2, concernente à limitação na pluralidade das fontes acionadas na maioria das matérias examinadas no estudo.

Poder-se-ia argumentar (a fim de sofisticar o conceito de "pluralidade" de vozes) que uma quantidade relevante de matérias apresentou apenas uma fonte, mas que, no todo, quando somadas, essas fontes caracterizariam um diagrama plural de vozes. Contudo, não é isso o que os dados da Tabela 2 permitem afirmar.

A essa altura, surge um questionamento acerca do papel a ser cumprido pela Agência Câmara: caberia a este veículo construir suas matérias de forma plural, a despeito da falta de pluralidade que pode ser o retrato das discussões do Parlamento? Ou ela estaria sendo fidedigna à realidade que busca retratar e cumprindo assim o que se espera de um veículo jornalístico? Tal questão é pertinente e merece reflexões mais aprofundadas, especialmente por se tratar de um veículo cujas configurações são marcadas pela ambiguidade ou hibridismo, como mostram Queiroz (2007) e Bernardes (2010).

Em tempo, é fundamental lembrar que a proposta do Jornalismo da Secom defende ir além daquela cobertura que caracteriza o Jornalismo comercial e da simples publicização do que ocorre na Casa. Logo, por mais que os veículos da Agência Câmara sejam institucionais, não é com uma marca "oficialesca" que eles procuram "se vender" à audiência. Não aprofundar a reflexão sobre a Reforma Política e não abrir espaço para a participação de atores externos às instituições do estado vai de encontro, assim, à própria proposta editorial.

Nesse sentido, sabe-se que não há contraposição entre o Jornalismo em mídias legislativas e a prestação de informações institucionais - afinal, sob o ponto de vista do sistema representativo, é útil ao público saber quais leis foram votadas e/ou aprovadas no Parlamento. Em outras palavras, noticiar as atividades parlamentares não equivale a somente promover a imagem pública de determinados agentes. O problema se apresenta quando o material se limita a adotar tal abordagem, indo de encontro, inclusive, à própria diretriz editorial da Agência. 
A outra questão investigada se refere à profundidade com que o tema "Reforma Política" foi abordado. Uma vez que o Manual da Câmara alega que o Jornalismo comercial "não tem sido capaz de [...] cumprir o papel de transmissor de toda a vasta gama de informações", a expectativa era que detalhes e alternativas ao projeto fossem explorados com maior exatidão. Da análise dessa questão, chega-se ao seguinte quadro:

Tabela 4: Abordagem do tema "Reforma política" nas notícias analisadas.

Elaborada pelos autores.

\begin{tabular}{|l|c|c|}
\hline \multicolumn{1}{|c|}{ Características } & $\begin{array}{l}\text { Números das } \\
\text { notícias }\end{array}$ & Quantidade \\
\hline $\begin{array}{l}\text { Notícia em que um dos pontos da reforma política é } \\
\text { aprofundado (são apontadas alternativas desse ponto, } \\
\text { vantagens e desvantagens envolvidas) }\end{array}$ & 14 & 1 \\
\hline $\begin{array}{l}\text { Notícias em que são apontadas algumas ponderações } \\
\text { relativas à reforma (como, por que é necessário fazê-la, } \\
\text { problemas que obstam a sua realização, que mudanças } \\
\text { precisam ser feitas) }\end{array}$ & $01,09,11$ e 12 \\
\hline $\begin{array}{l}\text { Notícias em que não há discussão de temas envolvidos na } \\
\text { reforma (ou seja, não se discutem as alterações que }\end{array}$ & $02,03,04,05$, & 12 \\
poderiam ser feitas com a reforma política, vantagens e & $13,15,16,17$ & \\
desvantagens etc.) & $06,07,10$, & \\
\hline
\end{tabular}

De fato, cinco das 17 notícias buscaram promover uma informação mais ampla a respeito da Reforma. Entretanto, na maior parte das vezes (em 12 notícias, ou 70\%), as notícias ficaram centradas em questões menores (como procedimentos burocráticos) e desconsideraram a necessidade de maior debate sobre a Reforma Política. Não foi atendido, desse modo, o objetivo de oferecer um estímulo ao debate público. O material examinado na amostra centra-se, preponderantemente, no jogo declaratório.

Naturalmente, não se quer traçar um modelo-ideal de matéria e exigir que toda a cobertura realizada pela Agência obedeça a uma mesma fôrma, pré-concebida. É inevitável, contudo, constatar que o padrão geral de cobertura jornalística da Agência não traz grandes alterações em comparação com o que ocorre no Jornalismo comercial - pelo menos no que concerne à amostra aqui enfatizada. Talvez seja possível dizer que o esforço dos veículos da 
MARQUES, Francisco Paulo Jamil Almeida \& NOGUEIRA, Leidyanne Viana. A cobertura jornalística em mídias legislativas: um estudo sobre a Agência Câmara.

Casa em apropriar-se da linguagem, das técnicas e das rotinas jornalísticas, como fazem as mídias das fontes (SANT’ANNA, 2009), culmina, mesmo que involuntariamente, com a apropriação de muitas deficiências do Jornalismo comercial. Porém, apenas uma análise comparativa e metodologicamente bem orientada poderá confirmar tal suspeita ${ }^{28}$.

Em suma, ao examinar a polifonia encontrada na amostra, obteve-se um índice reduzido de pluralidade de pontos de vista: apenas três das 17 notícias podem ser tidas como polifônicas. Além disso, ao verificar a profundidade com que o tema "Reforma Política" foi abordado nas matérias, percebeu-se que apenas uma notícia apresentou uma discussão ampla; outras quatro abordaram algumas questões importantes com relação à realização da Reforma; e 11 das 17 notícias não trouxeram discussão alguma a respeito do tema - limitando-se ao mero relato de eventos ou posições.

A pretensão aqui não é oferecer uma análise que dê conta de todos os aspectos considerados na elaboração das notícias por parte da Agência Câmara, uma vez que o material examinado, "como todo discurso, fica incompleto, sem início absoluto nem ponto final definitivo" (ORLANDI, 2000, p. 10). Acredita-se, contudo, que é possível ilustrar como as disputas ideológicas são patrocinadas por diferentes grupos, que, por sua vez, esforçam-se para se legitimarem ou resistirem ao exercício do poder, conforme atesta van Dijk (1995).

Há outras duas questões fundamentais relacionadas ao tema da investigação, mas que, por questões de espaço, não puderam ser contempladas neste artigo: 1) discutir a influência da Presidência da Câmara no processo produtivo da Agência (a escolha, no momento, foi enfatizar o material publicado, e não as rotinas dos profissionais ou as interferências testemunhadas na instituição); 2) comparar o material produzido pela Agência Câmara com os conteúdos veiculados na chamada "mídia tradicional”. Os desdobramentos desta investigação pretendem contemplar tais aspectos em nova oportunidade.

\footnotetext{
${ }^{28} \mathrm{O}$ projeto de investigação que originou este trabalho visa complementar os achados aqui apresentados quando sugere, em um outro texto, uma análise comparativa entre a cobertura da Agência Câmara e a cobertura oferecida por instituições do Jornalismo comercial (quality papers). Acredita-se que tal providência ajudará o campo de estudos, em um futuro próximo, a encontrar outros fatores que auxiliem os especialistas a mensurar as pressões políticas e econômicas sobre as práticas jornalísticas, tomando como referência a ideia de que os sistemas de mídia em cada país têm características singulares (HALLIN; MANCINI, 2004 e 2009).
} 


\section{REFERÊNCIAS}

AVRITZER, L.; ANASTASIA, F. 2006. Reforma política no Brasil. Belo Horizonte: UFMG.

BARROS, A. BERNARDES, C. B. LEMOS, C. 2008. As mídias legislativas e a redefinição da noticiabilidade política no Brasil. Em Questão, Porto Alegre, v.14, n.1, p.11-24, jan/jun. 2008.

BENETTI, M. 2006. Jornalismo e perspectivas de enunciação: uma abordagem metodológica. Revista Intexto, Porto Alegre, v. 1, n.14, p 1-11, 2006.

BENETTI, M. 2007. O Jornalismo como gênero discursivo. In: ENCONTRO NACIONAL DE PESQUISADORES EM JORNALISMO, 5., 2007, Aracaju. Anais eletrônicos... Universidade Federal de Sergipe, SBPJor, jul. 2007.

BENETTI, M. 2007. A ironia como estratégia discursiva da revista Veja. Revista Líbero, São Paulo, Ano X, n.20, p.35-46, dez 2007.

BERNARDES, C. B. 2007. O conceito de Jornalismo Público nos veículos da Câmara dos Deputados. Associação Brasileira de Pesquisadores em Jornalismo. In: ENCONTRO NACIONAL DE PESQUISADORES EM JORNALISMO, 5., 2007, Aracaju. Anais eletrônicos... Universidade Federal de Sergipe, SBPJor, jul. 2007.

BERNARDES, C. B. 2010. Política, institucional ou pública? Uma reflexão sobre a mídia legislativa da Câmara dos deputados. Rio de Janeiro. Tese (Doutorado em Ciência Política). Universidade Estadual do Rio de Janeiro (UERJ).

BERNARDES, C. B. 2011. Visibilidade política e controle da produção jornalística nos veículos de comunicação da Câmara dos Deputados. Revista Brasileira de Ciência Política, Brasília, n.6, p. 151-182, jul/dez. 2011.

BERNARDES, C. B.; MACEDO, S. M. 2014. Mudanças nas rotinas de produção do Jornalismo da Câmara dos Deputados: o processe de integração das mídias legislativas. Contemporânea: Comunicação e Cultura, v. 12, n ${ }^{\circ}{ }^{1}$. Salvador, p. 125-146.

BRANDÃO, E. P. 2012. Conceito de comunicação pública. In: DUARTE, J. (org). Comunicação Pública: Estado, mercado, sociedade e interesse público. São Paulo: Atlas.

BRESSER-PEREIRA, L. C. 2015. A construção política do Brasil. São Paulo: Editora 34.

BUCCI, E. 2008. Sobre Ética e Imprensa. 2. ed. São Paulo: Companhia das Letras.

BUCCI, E. 2008. Em Brasília, 19 horas: a guerra entre a chapa-branca e o direito à informação no primeiro governo Lula. Rio de Janeiro: Record.

CHARAUDEAU, P. 2007. O discurso das mídias. São Paulo: Contexto.

COURTINE, J. J. 2006. Metamorfoses do discurso político: derivas da fala pública. São Carlos: Claraluz. 
MARQUES, Francisco Paulo Jamil Almeida \& NOGUEIRA, Leidyanne Viana. A cobertura jornalística em mídias legislativas: um estudo sobre a Agência Câmara.

MENDES, P. Costa, F. PASSARINHO, N. 2013. Dilma propõe 5 pactos e plebiscito para constituinte da reforma política. Disponível em: <http://g1.globo.com/politica/noticia/2013/06/dilma-propoe-5-pactos-e-plebiscito-paraconstituinte-da-reforma-politica.html [15 out. 2014].

GLASSER, T. 1999. The Idea of Public Journalism. New York: Guilford Press.

GOMES, W. 2004. Transformações da política na era da comunicação de massa. São Paulo: Paulus.

HALLIN, D.; MANCINI, P. 2004. Comparing media systems: Three models of media and politics. New York: Cambridge University Press.

HALLIN, D.; MANCINI, P. (Eds.). 2012. Comparing media systems beyond the western world. New York: Cambridge University Press.

JARDIM, M. A. 2007. Antenas do Legislativo: os canais de televisão legislativos de Sarney a Severino. In: II CONGRESSO DA ASSOCIAÇÃO BRASILEIRA DE PESQUISADORES EM COMUNICAÇÃO E POLÍTICA, 2., 2007, Belo Horizonte, nov. 2007.

KOVACH, B. ROSENSTIEL,T. 2004. Os elementos do Jornalismo: o que os jornalistas devem saber e o público exigir. São Paulo: Geração Editorial.

MALAVAZI, A. (Org). 2004. Manual de Redação da Secretaria de Comunicação Social da Câmara dos Deputados. Brasília: Câmara dos Deputados, Secretaria de Comunicação Social.

MORAES, B. 2011. Jornalismo Público: um olhar sobre o Repórter Brasil. Brasília. Dissertação (Mestrado em Comunicação Social). Faculdade de Comunicação da Universidade de Brasília.

NICOLAU, J.; POWER, T. 2007. Instituições representativas no Brasil: balanço e reforma. Belo Horizonte: UFMG.

ORLANDI, E. 2000. Análise de discurso: princípios e procedimentos. Campinas: Pontes.

PÊCHEUX, M. 1997. Análise automática do discurso. In: GADET, F.; HAK, T. (Orgs.). Por uma Análise automática do discurso: uma introdução à obra de Michel Pêcheux. Campinas: Editora da Unicamp.

QUEIROZ, D. 2007. Jornalismo institucional nas TVs legislativas. Os casos do Brasil e do México. Dissertação (Mestrado em Comunicação). Universidade de Brasília.

SANT'ANNA, F. 2009. Mídia das fontes: um novo ator no cenário jornalístico brasileiro. Brasília: Senado Federal, Subsecretaria de Edições Técnicas.

TRAQUINA, N. 2005. O Estudo do Jornalismo no século XX. São Leopoldo: Unisinos.

VAN DIJK, T. A. 1995. Power and the news media. In: PALETZ, D. (Ed.) Political communication and action. Cresskill, NJ: Hampton Press. 
Revista Eletrônica de Ciência Política, vol. 7, n. 2, 2016

WEBER, M. H. 2007. Na comunicação pública, a captura do voto. LOGOS 27: Mídia e democracia. Rio de Janeiro, ano 14, p. 21-42, $2^{\circ}$ semestre 2007. 